\title{
Training by Using the Web Assessment of a Customer Orientation Course Used at the National Land Survey of Finland
}

\author{
Seija Kotilainen, National Land Survey of Finland
}

\begin{abstract}
In our society a great change in information technology has created a new paradigm for training. Trainees require rich learning environments supported by the World Wide Web. Furthermore, economic growth is no longer guaranteed for us. In this situation also we in real estate sector must look after that our training systems are modern and efficient.

This paper assesses a web-based distant training course, which is in use at the National Land Survey of Finland (NLS). The theme of this course is to teach basic facts about customer orientation. The first assessment was done by comparing factors of a good online course to the factors found in the online course. The second assessment was done by analyzing experiences from trainees. In assessments, qualitative research methods were used.
\end{abstract}

Keywords - Effectiveness, online course, real estate sector, surveying.

\section{INTRODUCTION}

Our society has faced great changes during the last decades. One change has occurred in information technology after World Wide Web was taken into use. This has created a new paradigm for training. Trainees nowadays require rich learning environments supported by the Web, i.e., Web-based training, WBT (Reigeluth \& Khan, 1993; Khan, 2001a, p. 5). Webbased training means an innovative approach to delivering hypermedia-based instructional programs to a remote audience. It utilizes attributes and resources of web to create well-designed, learner-centerd, interactive and engaging learning environments (Khan, 2001a, p. 5). Furthermore, economic growth is no longer guaranteed for us who live in Western countries. In this situation, we need all possible measures to support our economics. We must save money. For this purpose many companies and authorities pay attention to new possibilities of information technology - among them there is also web-based training. This also concerns our real estate companies.

When we use web-based training, we must use it cleverly. This means a systematic approach of creating online courses.
One systematic process for developing successful training is called instructional development (ID). Parts of this process are analysis, design, development, implementation, evaluation and management. This process can be used in both learning environments to individuals and groups (Villalba \& Romiszowski, 2001). In this paper, learning is defined as an enduring change in behavior or in the capacity to behave in a given fashion, which results from practice or other forms of experience (Schunk, 2012, p. 3).

Web-based learning courses are used in many organizations. In this paper, a course is assessed, which is in use at the National Land Survey of Finland. The theme of this course is to train basic facts of customer orientation. All employees ( 753 persons) working in cadastral survey processes all over Finland (in 34 different service points) were expected to take the course. Different kinds of trainees - both novice and very skilled employees - would take the same course.

The course consists of four online lessons (individual parts) and two team meetings (group learning parts). These face-toface meetings are held after the second lesson and after all four individual lessons have been completed. Each individual lesson takes about $30 \mathrm{~min}$. $-40 \mathrm{~min}$. and the team meetings take about 2-4 hours. Fig. 1 demonstrates the course.

A test list was done to assess the course. The list was formulated on the grounds of earlier studies and scientific learning theories. In the list there are only those factors, which shall appear when we are dealing with the online course of the NLS, rather than the entire web-based learning system or other types of courses.

This study discusses the following topics:

- Which methods, theories and basic issues must be taken into account when we are assessing a web-based training course?

- What are the results when we compare these methods and issues and the NLS online course?

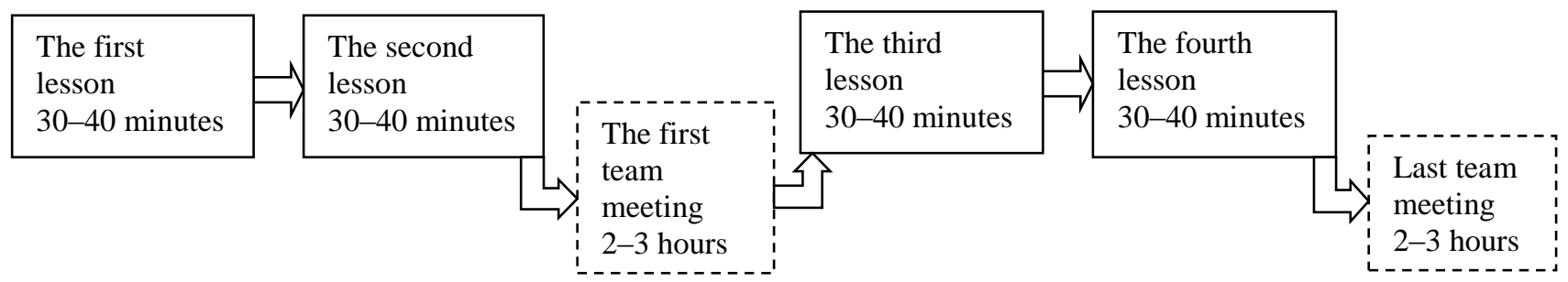

Fig. 1. Process and parts of the web-based course at the National Land Survey of Finland. 


\section{METHODS, THEORIES AND BASIC ISSUES}

In the study, qualitative research methods were used. Texts were analyzed by using the theory-based content analysis. Next, those theories are depicted which were used in the analysis.

There are numerous issues, which help to create a good learning environment. Many of these issues are interrelated and interdependent. Khan has built a framework of eight dimensions: pedagogical, technological, interface design, evaluation, management, resource support, ethical, and institutional (Khan, 2001b, pp. 76-78). Here we focus on pedagogical issues and content and interface design, as well as navigation. Some points of management are also described.

Pedagogical matter or learning theory is the first important factor we need to know when we are designing a course from the perspective of pedagogic issues. Theory, research and practice should be integrated. Commonly learning theories are divided into three different learning strategies: behavioral, cognitive and constructional strategies (Schunk, 2012, p. 20-22, 230-231).

According to the behavioral theory, learning occurs as a function of environmental factors. The stimuli come from outside of a learner and the response occurs within a learner. In this theory explanations for learning need not include thoughts, beliefs, feelings, because the causes of learning are observable environmental events. In contrast, cognitive theorists believe that learning is a mental phenomenon, where a learner constructs, acquires, organizes, codes, repeats and stores information in memory. Information processes are very important. This means that acquisition of knowledge and skills, the formation of mental structures, and the processing of information and beliefs are in focus. According to constructive theorists, trainees form or construct themselves much of what they learn and understand. For a teacher it is important to know how knowledge is constructed, not how it is acquired. Learning happens in situations and experiences are important (Schunk, 2012, pp. 21-22, 228-230; Bredo, 1977, pp. 3-45).

When we solve practical teaching problems, the first task is to build a link between the learning theory and the instructional design (Ertmer \& Newby, 2013, p. 44). However, each learning theory still describes the same phenomenon - learning. How does a course designer know which theory is best? Ertmer and Newby state that a designer must not ask "Which is the best theory?" but "Which theory is the most effective in fostering mastery of specific tasks by specific trainees?" What is most effective for novice trainees, would not be effective, efficient or stimulating for trainees who are familiar with the content. A designer must know both the knowledge phases of trainees and the requirements of the task to be learned (Ertmer \& Newby, 2013, pp. 44-45, 60-61).

Behavioral theory is effective when the purpose is to give basic information. After that they know WHAT. Cognitive strategy is useful when facts and rules are applied in unfamiliar situations (knowing WHY). If problems are illdefined, trainees need reflection-in-action. That means the use of constructive theories (Ertmer \& Newby, 2013, p. 60). As the online course of the NLS should give basic facts about customer orientation and some issues of practice, learning theories discussed here were behaviorism and cognitivism.

The first main issue is contents and interface design. The learning theories must be the bases of practical implementation. This means that learning theories must be applied when we are defining and organizing content, lesson logic, screen design and navigation of the online course (Villalba \& Romiszowski, 2001).

First, the connection between learning theories and basic instructional approach is described. Table I demonstrates this. In Table I, only behavioral and cognitive theories are depicted because these were the theories, which formulated the basis of the course.

Table I depicts that in behaviorism, learning is achieved through frequent response and immediate reinforcement of appropriate behavior. Performance is seen as a useful outcome of learning behavior. In designing, the task analysis should be used, which breaks down the behavior into a sequence of observable actions. Assessment practices must measure objectives according to performance indicators. In cognitivism, new information is built on existing knowledge. Relevant processing activities are stimulated to ensure that the trainee acquires the information or solves the problem. Assessments rely on observable behavior but infer specific mental operations based on the design of the test.

TABLE I

LEARNING THEORIES AND APPROACHES TO INSTRUCTION DESIGN (VILLALBA \& ROMISZOWSKI, 2001, PP. 327-328)

\begin{tabular}{|c|c|c|}
\hline Learning theory & Overall assumption / paradigm & Basic instructional approach \\
\hline Behaviorism & $\begin{array}{l}\text { - Behavior is a function of its consequences. Learning } \\
\text { is achieved through frequent response and } \\
\text { immediate reinforcement of appropriate behavior. } \\
\text { - Behavior and performance are either seen as } \\
\text { synonymous or performance is seen as the useful } \\
\text { outcome of learning behavior. }\end{array}$ & $\begin{array}{l}\text { - Instruction is designed to promote individual pacing and } \\
\text { progress. } \\
\text { - Instruction is designed by using a task analysis, which breaks } \\
\text { down the behavior into a sequence of observable actions. } \\
\text { - Assessment practices measure objectives in which behavior is } \\
\text { operationally defined and measured according to some } \\
\text { performance indicators. }\end{array}$ \\
\hline Cognitivism & $\begin{array}{l}\text { New information is built on existing knowledge. } \\
\text { Relevant processing activities are stimulated and } \\
\text { specific strategies are taught to ensure that the } \\
\text { learner efficiently acquires the information or solves } \\
\text { the problem. }\end{array}$ & $\begin{array}{l}\text { - Instruction is designed to promote a processing activity akin to } \\
\text { that of an expert. } \\
\text { - Assessment practices rely on observable behavior but infer } \\
\text { specific mental operations based on the design of the test. }\end{array}$ \\
\hline
\end{tabular}


The second issue is to decide what types of contents to include in the course and how contents should be organized. This is called lesson logic. Smith and Ragan offer an example of the components of cognitively based lesson logic (Table II). In the cognitively based lesson logic and learning (Table II), trainees are allowed to select those issues they want to learn. They can also ignore some specific issues. Thus, in cognitively based lesson logic, there is flexibility. In general level lesson logic based in behavioral theory consists of the setup stage, the initial presentation stage and the practice stage. The most common form of lesson logic is to present a statement or a rule, followed by an example and then a drill. In lesson logic based on behaviorism, there is not much flexibility to select components, which one would like to learn (Hannum, 2001, pp. 157-161).

The third major issue is to design individual screens, and the fourth issue is to enable navigation between screens. The design of a screen must follow a general pattern. All the screens should follow one standard. This standard identifies the layout of screens: the choice, color, and size of fonts, the background image or color, and the navigation scheme (Hannum, 2001, pp. 161-163).

An online course must have a good system of navigation, because trainees can easily become lost and give up. Navigation should allow them to move among sections of the course and select from content topics and lesson logic components (Hannum, 2001, p. 162).

TABLE II

COMPONENTS OF LESSON LOGIC (HANNUM, 2001, P. 161)

\begin{tabular}{|l|l|}
\hline \multicolumn{1}{|c|}{ Component } & \multicolumn{1}{c|}{ Specific issues } \\
\hline Active attention & - Use graphics, use animation, use \\
sounds.
\end{tabular}

\section{RESULTS}

Building the web-based course and teaching customer orientation were both done by the same project organization. Most members of the project group were surveyors who had practical experience of cadastral surveys. By this choice it was guaranteed that the designers of the course knew the knowledge phases of trainees. Another thing to take care of was the requirements of the task to be learned. That is why the project group got training better to understand customer orientation (Project Plan, 2013; Final Report, 2014, pp. 1-3).

The first purpose of the course was to give information about customer orientation (answers to WHAT-question). Secondly, the trainees should learn how this information could be used in practice. (Answers to WHY-question). This meant that both behavioral learning theory and cognitive learning theory were used in the design. The National Land Survey of Finland had decided before the beginning of the project that the platform of the course was Granite Parners' platform. The project had no opportunity to choose the platform. The executive group also decided that there would be one course for all (Memorandum of executive group, 2013).

NLS had conducted earlier studies (Wallius, 2007; Final report, 2009; Final report, 2012), which showed those customer satisfaction factors, which were essential, when employees were facing customers. The factors are called performance indicators. Dissertation of Kotilainen (2013, pp. 51-64) supports earlier findings of performance indicators. These indicators established important part of the contents.

The designing of the course was started with text writing a lot of texts about customer orientation and practice adaption. With the help of pedagogues texts were shortened. Texts were cut into pieces, which included the performance indicators. Part of these pieces connected behavior of person to the practice work of surveyors. In the end, only the most important issues were left in the texts. The project group also designed "active attention" - components such as manuscripts to videos and sound recordings. Comic strips, drills and a lot of graphics were designed for the course. Professionals were used to carry out all these "active attention" components.

Headings of the lessons are described in Table III. The titles of the lessons are: Introduction, I as a customer oriented activator, Practices and Challenging customer situations and reconciliation. The course contains texts, videos, sound recordings, pictures, exercises, graphics and tests. Purpose of the course is pointed out at the beginning of the first lesson. Content consists of texts, which break down the behavior into a sequence of observable actions. At the end of each lesson, the trainee must confirm that she or he has completed the lesson.

Two approaches in assessments of the course were used. The first one was a comparison of the factors of good online course to factors which were found from the online course. In this study a test list of the good factors was formulated (in Table III). They are related to pedagogical issues, content and interface design, screen design, navigation and some points of management. The second assessment was done by asking trainees about their experiences. 
TABLE III

HEADINGS OF LESSONS IN THE ONLINE COURSE OF NLS

\begin{tabular}{|c|c|}
\hline The lesson & Headings \\
\hline Introduction & $\begin{array}{l}\text { Main frame of this lesson (graphics) } \\
\text { Purpose of this course + video } 1 \\
\text { Customer orientation - why is it important? } \\
\text { Contents of customer orientation (oral and } \\
\text { written communication) } \\
\text { Behavior and different styles of behavior + } \\
\text { sound recordings } \\
\text { Drill: Test your basic style of behavior }\end{array}$ \\
\hline $\begin{array}{l}\text { I as a customer } \\
\text { oriented activator }\end{array}$ & $\begin{array}{l}\text { Main frame of this lesson (graphics) } \\
\text { My own attitude and customer orientation + } \\
\text { exercise } 1 \text { (writing results) } \\
\text { Behavior and successful interaction + exercise } 2 \\
\text { Trust - what it is and why it is important + } \\
\text { exercise 3(writing results) } \\
\text { Appreciate customers + exercise } 4 \\
\text { Communication } \\
\text { How to listen and ask + tests: I as a listener and } \\
\text { as a conversationalist } \\
\text { Practical questions to ask } \\
\text { Argumentation (what, when, how) + comic } \\
\text { strips } \\
\text { Vocal techniques and parts of voice control } \\
\text { Two tasks for team meeting }\end{array}$ \\
\hline Practices & $\begin{array}{l}\text { Main frame of this lesson (graphics) + video 2; } \\
\text { survey proceedings } \\
\text { Survey proceedings (listening vs hearing) } \\
\text { Practical tips for survey proceedings + exercise } \\
5 \text { + Video 3; terrain inspection + basic features } \\
\text { of it } \\
\text { Video 4; terrain works } \\
\text { Terrain work and customer orientation + } \\
\text { exercise } 6 \\
\text { E-mail and customer orientation + practical tips } \\
\text { Phone calls and customer orientation + video } 5 \\
\text { Negotiation skills + negotiation process } \\
\text { Tips for meeting a customer from a different } \\
\text { culture }\end{array}$ \\
\hline $\begin{array}{l}\text { Challenging } \\
\text { customer situations } \\
\text { and reconciliation }\end{array}$ & $\begin{array}{l}\text { Main frame of this lesson (graphics) } \\
\text { Challenging situation + practical tips to notice it } \\
\text { Examples: Procedures in municipal court } \\
\text { How to handle a challenging situation + } \\
\text { Practical tips to challenging situations } \\
\text { Co-operation with media + practical tips } \\
\text { Some tasks for final team meeting }\end{array}$ \\
\hline
\end{tabular}

\section{A. Comparison of Factors}

First, factors of good online course are compared to factors of the course of NLS. Table IV depicts assessment of the course in one table.

When we look at Table IV, we see that the course fulfils those requirements, which are the base of a good online course from the perspective of behavioral learning theory. It partly fulfils those requirements of cognitive learning theory, also because the course includes teamwork. In the team meetings employees can discuss and reflect their prior knowledge. The course also fulfils nearly all requirements that form the basis of a good online course from the perspective contents and interface design, screen design, navigation and management.

In contents and interface, there were deficiencies or poor design in previewing lessons. In the course there were some leading questions, but not in all parts. This was due to insufficient design. Also recall of the prior knowledge was mostly lacking from individual lessons, but it was part of team meetings. The individual lessons reflect mostly the perspective of behavioral learning theory. Technical database caused limitation in printing and saving material. Because of technical limitations, it was not possible to solve all problems connected with printing and saving.

\section{B. Experiences of Trainees}

The project group also asked trainees about their experiences. All 753 trainees in cadastral survey processes had an opportunity to answer a web-based questionnaire. 263 persons gave their answers. In the questionnaire, there were questions concerning general and detail contents of the course, and also functionality of technical issues. Attitudes towards customer orientation were mapped out. Questions were structural, but in the end a trainee could answer with his or her own words. The scale of structural questions was from 1 to 5 . The best evaluation meant 5 and the worst 1 . The detailed questions and means of answers are to be seen in Table $\mathrm{V}$.

We can see from Table $\mathrm{V}$ that attitudes of the trainees were good (mean 4.22) after completing the course. The trainees were also quite satisfied with the general contents of the course, mean 3.61. When we look at grades of detailed contents, mean is still higher than 3.97. The trainees are also very pleased with technical issues, mean 4.22.

When we look in more detail at Table $\mathrm{V}$ and answers to the open-ended questions (Final Report. 2014, Appendix 1, pp. 5-8), we can see that the trainees thought that they had gained objectives in learning. They also assessed the texts as easy to read. The trainees particularly liked the videos. Bad assessments were received for the issue that all employees studied the same course. There were some thirty experienced employees who though that the course gave them nothing. But even these trainees thought that the course was a good educational tool for inexperienced and badly behaving employees.

We can assess the answers of the trainees to the framework of the good online course components (Table IV). Then we can state that active attention, establishing purpose, arousing interest, processing information and examples, category of screen design, window elements and organizing them, text and graphic elements were successfully carried out. From the rest of elements shown in Table IV, there were no questions to the trainees in the questionnaire. 
TABLE IV

ASSESSMENT OF THE AdUlt TRAINING COURSE IN USE AT THE NATIONAL LAND SURVEY OF FINLAND

\begin{tabular}{|c|c|c|}
\hline Object of assessment, Issue & Specific theory/ factor or component & $\begin{array}{l}\text { Requirement } \\
\text { fulfilled }(x=\text { yes })\end{array}$ \\
\hline \multicolumn{3}{|l|}{1 Pedagogical issues } \\
\hline Learning theory & $\begin{array}{l}\text { - Behaviorism } \\
\text { - Cognitivism }\end{array}$ & $\begin{array}{l}X \\
X\end{array}$ \\
\hline \multicolumn{3}{|l|}{2 Contents and interface design } \\
\hline Active attention & $\begin{array}{l}\text { - Use graphics. } \\
\text { - Use animation. } \\
\text { - Use sounds. }\end{array}$ & $\begin{array}{l}X \\
X \\
X\end{array}$ \\
\hline Establish purpose & $\begin{array}{l}\text { - State purpose. } \\
\text { - Describe objectives in general terms. }\end{array}$ & $\begin{array}{l}X \\
X\end{array}$ \\
\hline Arouse interest & $\begin{array}{l}\text { - Describe shortly the importance and lessons of the course. } \\
\text { - Show how a lesson relates to their jobs. }\end{array}$ & $\begin{array}{l}X \\
X\end{array}$ \\
\hline Preview lesson & $\begin{array}{l}\text { - Summarize the lesson. } \\
\text { - Provide lesson outline. } \\
\text { - Provide lesson overview. }\end{array}$ & $\begin{array}{l}\text { not always } \\
\text { not always } \\
\mathrm{X}\end{array}$ \\
\hline Recall prior knowledge & $\begin{array}{l}\text { - Provide advance organizer. } \\
\text { - Point out what the learner already knows. } \\
\text { - Review prior knowledge. }\end{array}$ & $\begin{array}{l}\text { not always } \\
\text { not always } \\
\text { not always }\end{array}$ \\
\hline $\begin{array}{l}\text { Process information and } \\
\text { examples }\end{array}$ & $\begin{array}{l}\text { - Define new content. } \\
\text { - Describe new content. } \\
\text { - Give examples. } \\
\text { - Show graphic representations of content. }\end{array}$ & $\begin{array}{l}X \\
X \\
X \\
X\end{array}$ \\
\hline Focus attention & $\begin{array}{l}\text { - Highlight key content. } \\
\text { - Ask leading questions. } \\
\text { - Point out important aspects. }\end{array}$ & $\begin{array}{l}\mathrm{X} \\
\text { not always } \\
\mathrm{X}\end{array}$ \\
\hline \multicolumn{3}{|l|}{3 Screen design and navigation } \\
\hline Window elements & $\begin{array}{l}\text { - Menu bar (save, print, go). } \\
\text { - Toolbar (back, forward, stop). } \\
\text { - Location (URL of current page). } \\
\text { - Resizable windows. }\end{array}$ & $\begin{array}{l}\text { X, partly } \\
X \\
\text { not } \\
X\end{array}$ \\
\hline Organizing elements & $\begin{array}{l}\text { - Use headers (screen title). } \\
\text { - Have separate place for content (action instruction). } \\
\text { - Include navigation controls. }\end{array}$ & $\begin{array}{l}X \\
X \\
X\end{array}$ \\
\hline Text elements & $\begin{array}{l}\text { - Limit text to decrease scrolling. } \\
\text { - Use consistent fonts (one for headings, another for body). } \\
\text { - Limit text style. } \\
\text { - Select appropriate colors between foreground and background. }\end{array}$ & $\begin{array}{l}X \\
X \\
X \\
X\end{array}$ \\
\hline Graphic elements & $\begin{array}{l}\text { - Use for conveying instruction, not just to adorn. } \\
\text { - Consider size so loading time is not too long. } \\
\text { - Avoid unnecessary clutter of graphics. }\end{array}$ & $\begin{array}{l}X \\
X \\
X\end{array}$ \\
\hline Navigation & $\begin{array}{l}\text { - Moving between major sections is possible. } \\
\text { - Opportunity to select from contents and lesson logic components. }\end{array}$ & $\begin{array}{l}X \\
X\end{array}$ \\
\hline \multicolumn{3}{|l|}{4 Management } \\
\hline $\begin{array}{l}\text { Skills of project group } \\
\text { members }\end{array}$ & $\begin{array}{l}\text { - A designer knew the knowledge phases of trainees. } \\
\text { - A designer knew the requirements of the task to be learned. }\end{array}$ & $\begin{array}{l}X \\
X\end{array}$ \\
\hline
\end{tabular}

\section{Cost-effectiveness of the Online Course}

What about cost-effectiveness of online training? We can do some theoretical calculations. As comparison - NLS also has offered some employees face-to-face training courses. The subject of the courses has been customer orientation.
Education in these face-to-face courses has happened in small groups, 12-20 trainees in each group. One day of education has cost about 3600 euros (Memorandum, 2013). If we do some simple calculations to educate 750 employees for two days, we need approximately 75 education days. This costs 
TABLE $\mathrm{V}$

EXPERIENCES OF TRAINEES - THE AdULt TRAINING COURSE IN USE IN THE NATIONAL LAND SURVEY OF FINLAND

\begin{tabular}{|c|c|c|c|}
\hline Main part of enquiry & Question/Statement & $\begin{array}{c}\text { Mean, grade 1-5 } \\
(1=\text { Poor, } \\
5=\text { Excellent })\end{array}$ & $\begin{array}{l}\text { Mean of the } \\
\text { main part }\end{array}$ \\
\hline \multirow[t]{2}{*}{ Attitude } & $\begin{array}{l}\text { Customer orientation plays very important part in the National Land Survey of Finland } \\
\text { (NLS). }\end{array}$ & 4.59 & \\
\hline & It is cost-effective to act in customer oriented manner. & 3.85 & 4.22 \\
\hline \multirow[t]{6}{*}{ General contents } & The course is useful when meeting customers. & 3.60 & \\
\hline & The course raised new thoughts. & 3.26 & \\
\hline & Length of the course was well-chosen. & 3.66 & \\
\hline & In the course there were new aspects, and it contained new challenges. & 3.26 & \\
\hline & An interactive online course is very suitable as learning environment at the NLS. & 3.94 & \\
\hline & The layout of the course was good. & 3.94 & 3.61 \\
\hline \multirow[t]{6}{*}{ Detailed contents } & Objectives of the course were introduced clearly. & 3.84 & \\
\hline & I gained those objectives. & 3.95 & \\
\hline & Texts were easy to read. & 4.38 & \\
\hline & There were enough individual exercises. & 3.87 & \\
\hline & There were enough team exercises. & 3.85 & \\
\hline & There were enough videos. & 3.90 & 3.97 \\
\hline \multirow[t]{2}{*}{ Technical issues } & I could watch videos without problems. & 4.46 & \\
\hline & I could print out exercises without difficulties. & 3.77 & 4.12 \\
\hline
\end{tabular}

about 270000 euros. And there is some other spending to take into account, namely travelling expenses, when employees gather in small groups of 12-20 members. This can easily cost about 100000 euros. Thus, the total costs of face-to-face education could be approximately 370000 euros.

But, which are the costs of online course? Designing, building and assessing the web-based course had cost about 204000 euros (Final Report, 2014, p. 5). Theoretical calculations show that by using the online course, the NLS has already saved approximately 166000 euros.

(In these calculations we thought that the use of working hours was the same in both ways of teaching - namely 2 work days.) But that is not the whole truth. NLS can take advantage of the online course several years in the future. A face-to-face training course is a onetime course. Every new face-to-face course-day for 12-20 trainees is going to cost between 3600 and 4000 euros.

It seems that by using online courses companies can easily save 50-60 per cent of total costs of training courses when we compare the costs of online courses to the costs of face-to-face training course. Online courses seem to be very cost-effective in the cases when companies have many service points or many offices, which are situated far away from each other, even in different countries or in different continents.

\section{DISCUSSION}

There are both effective parts and non-effective parts in the web-based distant learning course of the NLS. Both experiences of the trainees and other assessments indicate this. Mostly the course was assessed to be very successful.

Successful components are connected with the use of videos, graphics, animation and sound recordings. The goal of the course was stated clearly and objectives were described in general terms. The course has connection to practice, because lessons are related to the jobs of the trainees. Key contents arose from the texts and important aspects were pointed out. Headers were used and texts were limited to decrease scrolling. In the course there were also some leading questions, which could help learning. Window elements, such as toolbar and resizable windows, were in use. In navigation, it was possible to move between major parts of lessons and it was also possible to select from content topics and lesson logic components.

Non-effective issues were also found. As the course was the same for all employees, some trainees were novice and others were highly experienced specialists. The project group could not find any easy measures regarding how to recall all of the prior knowledge of trainees. That is why individual lessons of the course did not contain recall of prior knowledge. Team meetings were thought to serve this function. But it seems that it was not a good solution. These team meetings with group discussions came too late. If there had been some recalling of prior knowledge even in the individual parts, the course would have been better. But it is difficult to design only one course for all employees where you could recall prior knowledge of all trainees. Maybe it would have succeeded if the course had had some alternative lessons for novice trainees and some other lessons for experts. Other solution to the problem could be the use of a lecturer via a video connection who is highly familiar with customer orientation issues. In this way team meetings could probably be guided to serve individual trainees better. On the other hand, the use of a distance education lecturer would increase costs. Therefore, maybe it would be 
best, first, to test with one team group if the use of a distance education lecturer would improve learning results.

Other poor issues of the course seemed to be lack of previews of lessons. There were no summaries at the end of the lessons. The summaries would have made the course longer, but they could have been used.

There were two main goals which were set to the NLS' online course. They were: offering a rich learning environment to the trainees and ensuring the course is cost-effective. The assessment done in this paper shows that both goals were achieved. Of course, you can always find something to improve in every course. At the moment it seems that the NLS shall continue the use of web-based distance training.

The scope of this research was in land management activities, in detail: how we can make employees more efficient by training employees efficiently. If we think of future research directions in this scope, there are two directions to mention. It would be good to study other online courses related to different subjects. That way we could have more knowledge about costs and savings, which online courses can offer. When the steps in the information technology are so fast, we also need new theories by which we can test our online courses in the future.

Our society will be challenged by great changes in the information technology in the future. This will affect not only the training courses of the National Land Survey of Finland but also all real estate agencies in Europe. All of us in the real estate field must ensure that our training systems are effective. One good way to secure this is to increase the use of online courses.

\section{REFERENCES}

Bredo, E. (1997). The social construction of learning. In G Phye (Ed.). Handbook of academic learning: The construction of knowledge. Academic Press. New York. http://dx.doi.org/10.1016/B978-012554255-5/50002-8

Ertmer, P. A. \& Newby, T. J. Behaviorism, cognitivism, constructivism: Comparing critical features from an instructional design perspective. Performance Improvement Quarterly, 26 (2), pp. 43-71. International Society for Performance Improvement. 2013.

Final Rapport. (2014). TOIMAS2/tko-project. (in Finnish). The National Land Survey of Finland.

Final Rapport. (2012). Customer orientation in cadastral survey proceedings. (in Finnish). The National Land Survey of Finland.
Final rapport. (2009). Customer oriented land consolidation. (In Finnish). The National Land Survey of Finland.

Hannum, W. (2001). Design and development issues in web-based training. Khan (Ed.). Web-Based training. pp. 155-164. Educational Technology Publications. Inc., Englewood Cliffs, New Jersey 07632.

Khan, B.H. (2001a). Web-Based training: An introduction. In Khan (Ed.). Web-Based training. pp. 5-12. Educational Technology Publications. Inc., Englewood Cliffs, New Jersey 07632.

Khan, B.H. (2001b). A framework for web-based learning. In Khan (Ed.). Web-Based training. pp. 75-98. Educational Technology Publications. Inc., Englewood Cliffs, New Jersey 07632.

Kotilainen, S. (2013). Developing conflict resolution in highway and railway projects - Perspective of real property owner. (In Finnish). Aalto University publication series DOCTORAL DISSERTATIONS 82/2013.

Memorandum of executive group 11.4.2013. (In Finnish). TOIMAS2/tkoproject. The National Land Survey of Finland.

Memorandum 5.3.2013. (In Finnish). TOIMAS2/tko-project. The National Land Survey of Finland.

Project Plan 13.2.2013. (In Finnish). TOIMAS2/tko-project. The National Land Survey of Finland.

Reigluth, M.C., Khan, B. (1993). Educational Systems Design: An Integrated, Disciplined Inquiry in Schools of Education. EDUCATIONAL TECHNOLOGY/June 1993. pp. 36-40.

Schunk, D.H. (2012). Learning theories, an educational perspective. Sixth Edition. The University of North Carolina at Greensboro. Pearson Education, Inc., publishing as Allyn \& Bacon. First Edition 1991.

Villalba, C \& Romiszowski, A. J. (2001). Current and ideal practices in designing, developing, and delivering web-based training. In Khan (Ed.). Web-Based training. pp. 325-342. Educational Technology Publications. Inc., Englewood Cliffs, New Jersey 07632.

Wallius, K. (2007). Customer orientation in land consolidation. (In Finnish). Scholary Thesis. Faculty of Administrative Sciences. University of Vaasa.

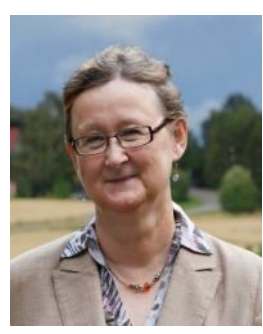

Seija Kotilainen The Academic experience: Doctor of Science in Technology (Land Management), Aalto University, 2013, Licentiate of Technology in Surveying, Helsinki University of Technology (HUT), 2003.

Practical experience: Senior Advisor at the Support Services of the National Land Survey of Finland since 2014. Senior Advisor at the Development Centre of the National Land Survey of Finland in the period of 1990-2013. Cadastral Surveyor in several District Survey Offices in the period of 1981-1990.

Activities in homeland and international relations: Chair of the Finnish Society of Surveying Sciences (2004). Member of the Board of the Finnish Society of Surveying Sciences (1993-94, 2003, 2005).

Contact data: National Land Survey of Finland;

E-mail: seija.kotilainen@nls.fi 